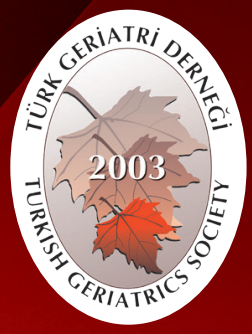

Turkish Journal of Geriatrics DOI: 10.31086/tjgeri.2018.63 2018;21 (4):565-572

- Osman ÖNDAŞ ${ }^{1}$

- Erdinç BOZKURT²

CORRESPONDANCE

Osman ÖNDAŞ

Atatürk University, Faculty of Medicine,

Department of Ophthalmology, Erzurum, Turkey

Phone: 04423447984

e-mail: osmanondas82@gmail.com

Received: 11/07/2018

Accepted: 22/10/2018

Atatürk University, Faculty of Medicine, Department of Ophthalmology, Erzurum, Turkey

Kafkas University, Faculty of Medicine, Department of Ophthalmology, Kars, Turkey

\section{PROGNOSIS AFTER EARLY HYPERBARIC OXYGEN THERAPY IN GERIATRIC PATIENTS WITH CENTRAL RETINAL ARTERY OCCLUSION}

\section{Abstract}

Introduction: This study was conducted to evaluate the results of early hyperbaric oxygen therapy (HBOT) in patients 65 years and older with Central retinal artery occlusion (CRAO).

Materials and Method: The files of patients who presented with CRAO between February 2010-June 2016 were retrospectively analyzed. Age, gender, time between symptom onset-first HBOT session, other treatments, follow-up period, intraocular pressure(IOP), visual acuity(VA) were reported. Color fundus photography, fundus fluorescein angiography, optic coherence tomography (OCT) were done. HBOT was initiated in the first 8 hours after visual symptom onset. Wilcoxon test was used in statistical analysis, $\mathrm{P}<0.05$ accepted as statistically significant.

Results: 20 eyes of 20 patients with CRAO were included to the study. Thirteen (65\%) of the patients were male, 7(35\%) female; mean age was 65-87(76.3 \pm 9.6$)$ years. Ocular massage, antiglaucomatous drops, acetylsalicylic acid, oral acetazolamide, mannitol (i.v) treatments were applied. Anterior chamber paracentesis was performed. All patients had HBOT within the first 8 hours, 20 sessions of HBOT (2.4atm, 120 min) were applied. Time between symptom onsetfirst HBOT session was 5.3 hours. Follow-up time was 16.3 months. IOP was $12.23 \pm 3.41 \mathrm{mmHg}$ before treatment, $12.97 \pm 5.58 \mathrm{mmHg}$ after treatment. VA was $1.92 \pm 3.26$ (logMAR) at presentation, $1.1 \pm 7.80$ after treatment $(p<0.01)$. VA improved in 13 eyes $(65 \%)$, unchanged in 6 eyes(30\%), decreased in 1 eye $(5 \%)$. In OCT examination, mean macular thickness was $358 \mu \mathrm{m}$ at presentation, $177 \mu \mathrm{m}$ at 6 months after treatment $(p<0.01)$.

Conclusion: In patients 65 years of age and older with SRAT; HBOT results are quite satisfactory if it is initiated within the first 8 hours.

Keywords: Retinal artery occlusion; hyperbaric oxygenation; Aged

ARASTIRMA

\section{SANTRAL RETINAL ARTER TIKANIKLIĞI GEÇiREN GERIATRIK YAŞ GRUBUNDAKI HASTALARDA ERKEN UYGULANAN HIPERBARIK OKSIJEN TEDAVISININ PROGNOZU}

\section{$\ddot{O ̈ z}_{z}$}

Giriș: Bu çalışma santral retinal arter tıkanıklığı (SRAT) geçiren 65 yaşve üzerindeki hastalarda erken uygulanan hiperbarik oksijen tedavisinin (HBOT) sonuçlarının değerlendirilmesi amacıyla yapılmıştır.

Gereç ve Yöntem: Şubat 2010-Haziran 2016 tarihleri arasında SRAT nedeniyle başvuran hastaların dosyaları retrospektif olarak incelendi. Yaş, cinsiyet, semptom başlangıcı ile ilk HBOT seansı arasındaki süre, diğer tedaviler, takip süresi, göz içi basıncı (GiB), görme keskinliği (GK) kaydedildi. İlk muayenelerde ve kontrollerde; renkli fundus fotoğrafı, fundus floresein anjiografi, optik koherens tomografi (OCT) çekildi. Tüm hastalara görsel semptomların başlamasından itibaren ilk 8 saat içerisinde HBOT başlandı. İstatistiksel analizlerde Wilcoxon testi kullanıldı, $\mathrm{p}<0.05$ olması anlamlı kabul edildi.

Bulgular: Çalışmaya SRAT geçiren 20 hastanın 20 gözü dahil edildi. Hastaların 13'ü (\%65)

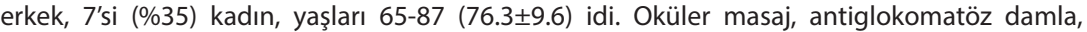
asetilsalisilik asit, oral asetazolamid, mannitol (i.v) tedavisi uygulandı. Ön kamara parasentezi yapıldı. Tüm hastalara HBOT ilk 8 saat içerisinde başlandı ve toplam 20 seans HBOT (2.4atm, $120 \mathrm{~min}$ ) uygulandı. Sikayetler ile ilk HBOT arasındaki süre ortalama 5.3 saat idi. Ortalama takip süresi 16.3 aydı. Tedavi öncesi GiB $12.23 \pm 3.41 \mathrm{mmHg}$, tedavi sonrası $12.97 \pm 5.58 \mathrm{mmHg}$ idi. Başvuru anında GK ortalama 1.92 \pm 3.26 (logMAR), tedavi sonrasında $1.1 \pm 7.80(p<0.01)$ idi. GK 13 (\%65) gözde arttı, 6 (\%30) gözde değişmedi, 1 (\%5) gözde azaldı. OCT incelemesinde olguların ortalama makula kalınlığı başvuru anında $358 \mu \mathrm{m}$, tedavi sonrası 6. ayda $177 \mu \mathrm{m}(\mathrm{p}<0.01)$ idi.

Sonuç: SRAT geçiren 65 yaş ve üzerindeki hastalarda; ilk 8 saat içerisinde başlandığı takdirde, HBOT sonuçları oldukça tatminkardır.

Anahtar sözcükler: Retinal arter tıkanıklığl; Hiperbarik oksijenasyon; Yaşlı 


\section{INTRODUCTION}

Central retinal artery occlusion (CRAO) accounts for the majority of retinal artery occlusion cases and generally reduces vision to the level of light perception or hand movements. The diagnosis is established by medical history and ophthalmoscopic examination. Relative afferent pupillary defect is an important clinical finding suggestive of CRAO in the early phase, when fundus findings are not yet prominent. In the first week, cherry-red spot (90\%), retinal opacities (58\%), pallor (39\%), arterial attenuation (32\%), and optic disc oedema (22\%) may be seen in the posterior pole, while optic atrophy (58\%), arterial attenuation (58\%), cilioretinal collaterals (18\%), and macular retinal pigment epithelial changes $(18 \%)$ occur in the late phase (1). The 'cherry-red spot' sign frequently seen in ophthalmoscopic examination in the first week refers to the red appearance of the macula, which continues to be perfused by the choroid, surrounded by the pale fundus resulting from retinal ischaemia and oedema. This sign disappears after about 4 to 6 weeks when the oedema resolves (2).

The risk factors for CRAO include male sex, age 65 and older, hypertension, diabetes, hyperlipidaemia, obesity, smoking and alcohol use, sedentary lifestyle, haematological disorders, systemic vasculitis, oncologic diseases, local eye trauma, retinal surgeries causing sudden increase in intraocular pressure (IOP), retrobulbar injections, prepapillary arterial loop, and optic disc drusen (3).

Fundus fluorescein angiography (FFA), optical coherence tomography (OCT), electroretinography (ERG), automated visual field (AVF) examination, and colour Doppler ultrasound (CDUS) are important in the diagnosis of CRAO. In FFA, the retinal artery filling time and arteriovenous transit time are prolonged. Leakage is observed from the perfused capillaries within the first week of obstruction. In the late phase, there is no leakage, but vascular changes are evident and the optic disc remains hypofluorescent (4). Findings on OCT include thickening of the retinal layers, oedema of the retina and optic nerve head. The electroretinogram (ERG) shows a normal a-wave, which represents the photoreceptor response, while the b-wave showing Müller and bipolar cell responses is reduced or absent (5). AVF reveals visual field defects proportional to the extent of neurosensory layer damage. Limited temporal and peripheral vision is often preserved. CDUS provides information about reduced or absent flow in the central retinal artery (6).

Treatment of CRAO is urgent, because animal studies have shown that irreversible damage occurs in the neurosensory layer when retinal occlusion lasts more than 240 minutes (7). The aim of treatment is to rapidly reduce IOP and dislodge the embolus with the help of intravenous perfusion pressure. This is currently done using methods; such as ocular massage, anterior chamber paracentesis, systemic acetazolamide and mannitol therapy (8). Various treatment methods with unproven efficacy are also used to restore retinal circulation; such as aspirin, calcium channel blockers, systemic vasodilators, intravenous bolus methylprednisolone, and isovolumic hemodilution. Systemic antifibrinolytic agents, such as streptokinase, urokinase, and tissue plasminogen activators, must be used carefully because of possible adverse effects. However; many studies have demonstrated the efficacy of fibrinolytic therapy in the first 6.5 hours (9).

Hyperbaric oxygen therapy (HBOT) is another method used to treat patients with CRAO. In HBOT, $95 \%$ (carbogen) or 100\% oxygen is applied at pressures of 2 atmospheres (atm), 2.4 atm, or 
$2.8 \mathrm{~atm}$ in order to increase oxygenation of the retina (10). In our study; we aimed to evaluate the results of early HBOT in patients 65 years and older with CRAO.

\section{MATERIALS AND METHOD}

The medical records of patients who presented to The Atatürk University Faculty of Medicine, Department of Ophthalmology with CRAO, between February 2010 and June 2016 were analysed retrospectively. The study adhered to the principles of the Declaration of Helsinki. The patients age and sex, time from symptom onset to first HBOT session, other treatments, follow-up time, pretreatment and posttreatment IOP (Canon TX 20p noncontact tonometer), and best corrected visual acuity (BCVA) were recorded. All patients underwent a full ophthalmologic examination, including colour fundus photography, FFA (Kowa VX-10a), and OCT (Optovue RTvue RT-100) imaging. HBOT was initiated within the first 8 hours after the onset of visual symptoms in all cases.

\section{Statistical analysis}

Descriptive and statistical analyses of the data were performed using SPSS version 21.0 software. The Wilcoxon signed rank test was used to compare pre- and posttreatment values. A $\mathrm{p}$ value $<0.05$ was considered to indicate statistical significance.

\section{Ethical considerations}

The local ethic committee approval was obtained (2018/13-136).

\section{RESULTS}

Twenty eyes of 20 patients with CRAO were included in the study. Thirteen (65\%) of the patients were male and 7 (35\%) were female; the mean age was 76.3 \pm 9.6 (range, 65-87) years. All patients were administered topical antiglaucomatous drops (dorzolamide-timolol, brimonidine tartrate, latanoprost), $250 \mathrm{mg}$ oral acetazolamide, and $1.5-2 \mathrm{~g} / \mathrm{kg}$ intravenous $20 \%$ mannitol to reduce IOP. Intermittent ocular massage (10-15 seconds with sudden release) was applied, and 0.1-0.4 mL anterior chamber paracentesis was performed under sterile conditions.

All patients underwent a total of 20 HBOT sessions of $2.4 \mathrm{~atm}$ for 120 minutes, starting within 8 hours after the onset of visual symptoms. The mean time between symptom onset and first HBOT was 5.3 hours. The mean follow-up time was 16.3 months. The mean IOP was $12.23 \pm 3.41$ $\mathrm{mmHg}$ before treatment and $12.97 \pm 5.58 \mathrm{mmHg}$ after treatment.

VA was 1.92 \pm 3.26 2.0-1.6) (logMAR) at presentation, $1.1 \pm 7.80 \quad(1.52-0.92) \quad$ after treatment $(p<0.01)$. BCVA increased in 13 eyes $(65 \%)$, remained unchanged in 6 eyes $(30 \%)$, and decreased in 1 eye (5\%). All patients underwent colour fundus photography and FFA examination at the time of application and in the sixth month; images were recorded (Figures 1, 2). On OCT examination performed at presentation and 6 months after treatment, the mean macular thickness was 358 and $177 \mu \mathrm{m}$, respectively $(p<0.01)$ (Figures 1, 2). 


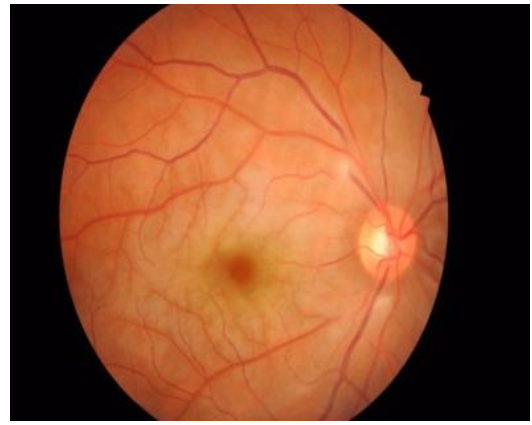

(a)

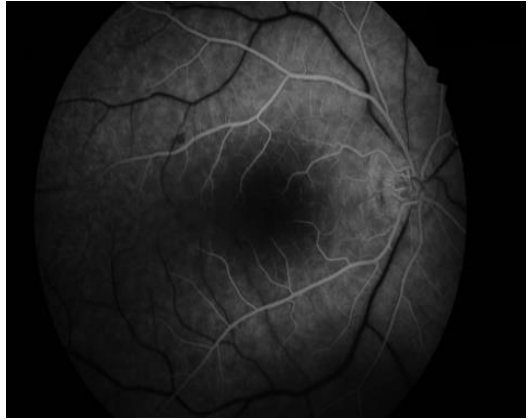

(b)

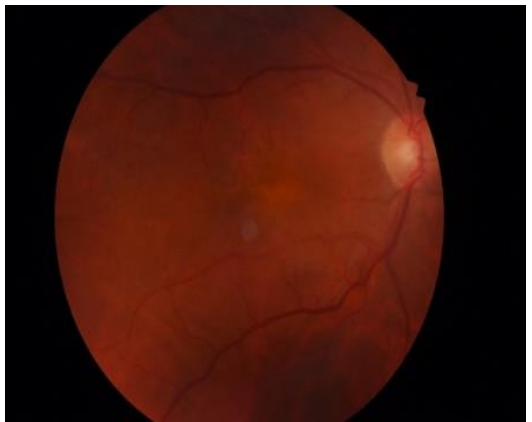

(c)

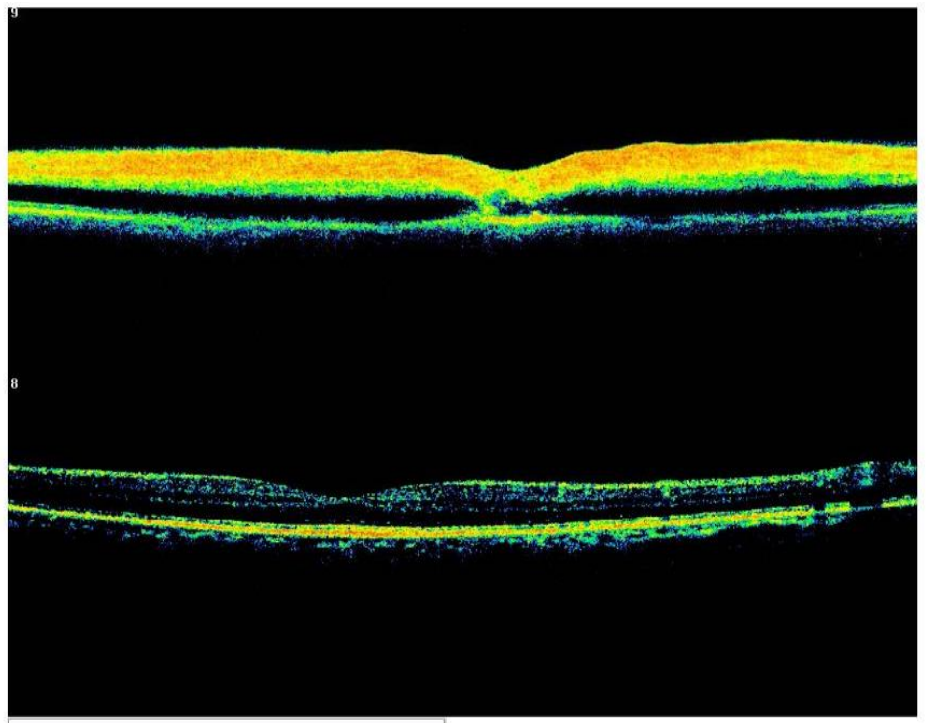

(d)

(a) Colour fundus photograph of the right eye showing CRAO with cherry-red spot, common paleness and oedema in retina

(b) Corresponding FFA showing filling defect in retinal arterioles

(c) 6 month fundus photograph shows recovery of the retinal paleness.

(d) OCT examination performed at first visit showing increased reflectivity in inner retinal layers, reduced reflectivity in the area of perifoveal retinal pigment epithelium (central macular thickness: $357 \mu \mathrm{m}$ ) (above). In the sixth month OCT examination showing; atrophy in neurosensory retina, decrased reflectivity, flattening in foveal contour (central macular thickness: $231 \mu \mathrm{m})$ (bottom).

Figure 1. 77-year-old male patient. 


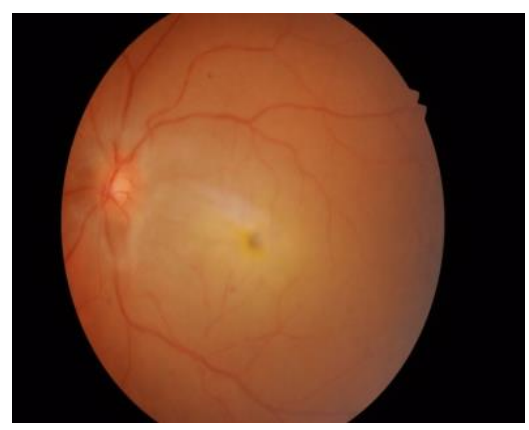

(a)

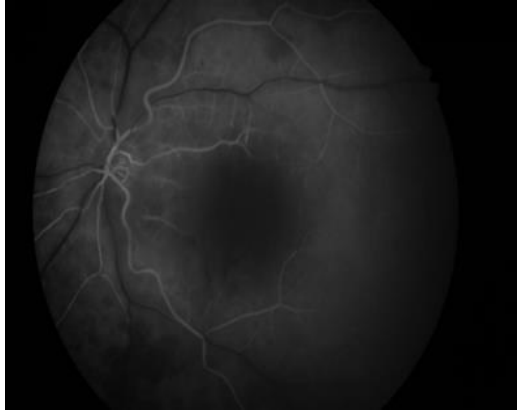

(b)

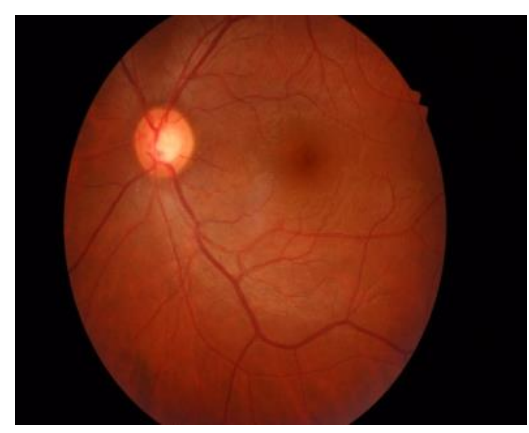

(c)

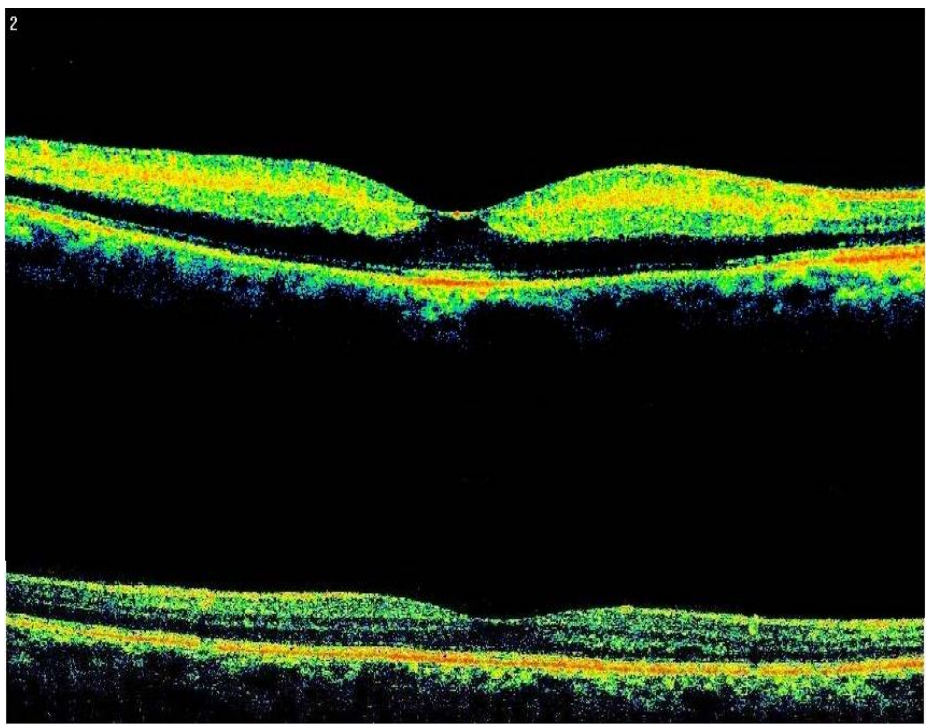

(d)

(a) Colour fundus photograph of the left eye reveals CRAO with significant retinal oedema and pallor

(b) Corresponding FFA shows filling defect in retinal arterioles and infarcted retina

(c) 6 month fundus photograph shows recovery of the retinal paleness.

(d) OCT examination performed at first visit showing; increased reflectivity in inner retinal layers, reduced reflectivity in the area of perifoveal retinal pigment epithelium (central macular thickness: $385 \mu \mathrm{m}$ ) (above). In the sixth month OCT examination showing; atrophy in neurosensory retina, decrased reflectivity, flattening in foveal contour (central macular thickness: $273 \mu \mathrm{m})$ (bottom).

Figure 2. 68-year-old female patient. 


\section{DISCUSSION}

CRAO is an emergency condition, the equivalent of an ocular stroke, and occurs at a rate of about $1 / 10,000$ (11). There are four types of CRAO (12). Nonarteritic permanent CRAO; Accounts for two-thirds of all CRAO cases; occurs due to thromboembolism from atherosclerotic vessels. Nonarteritic transient CRAO; Comprises 15\% to 17\% of all CRAO cases; has the best visual prognosis. Nonarteritic CRAO with cilioretinal sparing; Central vision may be preserved in CRAO patients with perfusing cilioretinal artery due to continued supply to the macula. Arteritic CRAO; Occurs due to giant cell arthritis; accounts for $4.5 \%$ of all CRAO cases.

A prospective study of 260 eyes with CRAO showed that people suffer profound monocular visual loss, with $80 \%$ of patients having a visual acuity (VA) of $20 / 400$ or worse (12). In four types; nonarteritic transient CRAO has the best visual prognosis after the treatment. Our cases were nonarteritic permanent CRAO in our study. Case presentations in all studies do not differentiate the degree of CRAO severity; therefore, it is impossible to compare the data. In the reports presenting successful treatment, the patients had not been divided into groups according to their CRAO stage.

Many treatments have been used for CRAO. Although ocular massage and anterior chamber paracentesis have been practised for 130 years, some studies have indicated that these measures can cause extreme IOP fluctuations and thus have an adverse effect on ischaemic retinal neurons if performed incorrectly (13). Intravenous fibrinolysis therapy has been shown to be effective if initiated within 4.5 hours after symptom onset (14). However, due to the high risk of cardiac and cerebrovascular disease in patients with CRAO, the use of thrombolytic agents and surgical embolectomy has not been widely accepted because of the high risk of haemorrhage (15).

While the inner two-thirds of the retina is fed by the central retinal artery, the outer third is fed by diffusion from the choroid; therefore, choroidal circulation is important in patients with CRAO. Oxygen dissolved at high concentration in the plasma may perfuse from the choroidal circulation into the inner retinal layers until reperfusion can be achieved. In HBOT, 100\% oxygen applied at $2.4 \mathrm{~atm}$ increases plasma oxygen concentration by 17 -fold, from 0.32 to $6 \mathrm{~mL} / 100 \mathrm{~mL}$, allowing more oxygen to reach the retina (16). For this purpose, we subjected 20 CRAO patients to 20 HBOT sessions, each lasting 120 minutes. We then evaluated whether there were changes in BCVA, IOP, and OCT measurements of macular thickness after treatment.

HBOT has been used in the treatment of many diseases since the 1600s. Clinical studies were first published in 1956 by Ite Boerema, the chair of the Department of Surgery at the University of Amsterdam. HBOT administered intraperitoneally during cardiac surgery has been shown to extend safe surgery time, and HBOT was shown to be effective in necrotising infected tissues and nonhealing ulcers (17).

Several studies have demonstrated that HBOT exhibits anti-inflammatory effects by reducing inflammatory agents such as interleukin (IL)-1, IL-6, IL-8, IL-10, and tumour necrosis factor alpha (TNF- $\alpha$ ) and reduces tissue oedema by vasoconstriction (18). Weiss et al. emphasised that HBOT reduces macular oedema and should be a part of CRAO treatment (19). In the present study, we observed a significant decrease in macular thickness measured on OCT after HBOT $(p<0.01)$.

Murphy et al. showed that HBOT reduced damage in the ischaemic area by increasing oxygenation of the inner and outer retinal layers via the choroidal circulation (11). There are many studies in the literature concerning visual improvement with HBOT $(11,20)$. In our study, there was significant improvement in visual prognosis in 13 eyes of 20 patients.

Hayreh et al. showed that HBOT after CRAO reduced apoptotic cell loss from $58 \%$ to $30 \%$ in a 
study of rhesus monkeys (7). In addition, studies on ischaemic rat models demonstrated that HBOT exerted an anti-apoptotic effect by reducing caspase-3 secretion (21). In animal studies of diabetic retinopathy, HBOT has been shown to reduce disruption of the blood-retinal barrier and facilitate repair of retinal damage (22).

Although numerous studies have shown the value of HBOT in the treatment of CRAO, there is no consensus as to when HBOT should be initiated or for how long it should be given. Butler et al. reported achieving good visual outcomes in a patient group who received HBOT within 12 hours after symptom onset (23). Beiran et al. emphasised the need to start HBOT within the first 8 hours after vision loss (24). The Undersea and Hyperbaric Medical Society reported that HBOT should be initiated in the first

\section{REFERENCES}

1. Beatty S, Eong KGA. Acute occlusion of the retinal arteries: current concepts and recent advances in diagnosis and management. J Accid Emerg Med 2000;17:324-9. (PMID:11005400).

2. Beiran I, Goldenberg I, Adir Y, et al. Early hyperbaric oxygen therapy for retinal artery occlusion. Eur J Ophthalmol 2001;11(4):345-50. (PMID:11820305).

3. Butler FK, Hagan C, Murphy-Lavoie H. Hyperbaric oxygen therapy and the eye. Undersea Hyperb Med 2008;35:333-85. (PMID:19024664).

4. Callizo J, Feltgen N, Pantenburg Setal. Cardiovascular risk factors in central retinal artery occlusion: results of a prospective and standardized medical examination. Ophthalmology 2015;122:1881-8. (PMID:26231133).

5. Chang $\mathrm{YH}$, Chen $\mathrm{PL}, \mathrm{Tai} M C$, et al. Hyperbaric oxygen therapy ameliorates the blood-retinal barrier breakdown in diabetic retinopathy. Clinical and Experimental Ophthalmology 2006;34:584-9. (PMID:16925707).

6. Chen X, Duan XS, Xu LJ, et al. Interleukin-10 mediates the neuroprotection of hyperbaric oxygen therapy against traumatic brain injury in mice. Neuroscience 2014;266:235-43. (PMID:24291771).
24 hours after symptom onset, but better outcomes are achieved when it is initiated within 12 hours (25). In our study, patients given HBOT at a mean of 5.3 hours after symptom onset experienced significant improvement in visual prognosis.

In addition to the requisite medical interventions, HBOT is a safe adjunctive therapy for patients aged 65 and older with CRAO and yields favourable outcomes when initiated within the first 8 hours after occlusion.

Patients with CRAO should undergo HBOT within the first 8 hours as a reliable noninvasive treatment method.

\section{Conflicts of interest}

The authors declare no conflict of interest.

7. Cope A, Eggert J, O'Brien E. Retinal artery occlusion: visual outcome after treatment with hyperbaric oxygen. Diving Hyperb Med Journal 2011;41:135-9. (PMID:21948498).

8. Dattilo $M$, Biousse $V$, Newman NJ. Update on the management of central retinal artery occlusion. Neurol clin 2017;35(1):83-100. (PMID:27886897).

9. Feiss A, Cal O, Kehrein S, et al. Anterior chamber paracentesis after central retinal artery occlusion: a tenable therapy. BMC Ophthalmol 2014;14:28. (PMID:24612658).

10. Fraser SG, Adams W. Interventions for acute nonarteritic central retinal artery occlusion. Cochrane Database Syst Rev 2009;1:1989. (PMID:19160204).

11. Hattenbach LO, Kuhli-Hattenbach C, Scharrer I, Baatz H. Intravenous thrombolysis with low-dose recombinant tissue plasminogen activator in central retinal artery occlusion. Am J Ophthalmol 2008;146:700-6. (PMID:18718570).

12. Hayreh S, Jonas JB. Optic disk and retinal nerve fiber layer damage after transient central retinal artery occlusion: an experimental study in rhesus monkeys. Am J Ophthalmol 2000;129:786-95. (PMID:10926989). 
13. Hayreh SS, Podhajsky PA, Zimmerman MB. Retinal artery occlusion: associated systemic and ophthalmic abnormalities. Ophthalmology 2009;16:1928-36. (PMID:19577305).

14. Hayreh SS, Zimmerman MB. Central retinal artery occlusion: visual outcome. Am J Ophthalmol 2005;140(3):376-91. (PMID:16138997).

15. Hayreh SS, Zimmerman MB. Fundus changes in central retinal artery occlusion. Retina 2007;27:27689. (PMID:17460582).

16. Kranke $\mathrm{P}$, Bennett $\mathrm{MH}$, Martyn-St James $\mathrm{M}$, et al. Hyperbaric oxygen therapy for chronic wounds. Cochrane Database of Syst Rev 2015;24:6. (PMID:26106870)

17. Liu $X H$, Yan $H, X u M$, et al. Hyperbaric oxygenation reduces long-term brain injury and ameliorates behavioral function by suppression of apoptosis in a rat model of neonatal hypoxia-ischemia. Neurochem Int 2013;62(7):922-30. (PMID:23499794).

18. Menzel-Severing J, Siekmann U, Weinberger A, et al. Early hyperbaric oxygen treatment for nonarteritic central retinal artery obstruction. Am J Ophthalmol 2012;153:454-9. (PMID:21996308).

19. Murphy-Lavoie H, Butler F, Hagan C. Central retinal artery occlusion treated with oxygen: a literature review and treatment algorithm. Undersea Hyperb Med 2012;39(5):943-53. (PMID:23045923).
20. Nedelmann M, Graef M, Weinand F, et al. Retrobulbar spot sign predicts thrombolytic treatment effects and etiology in central retinal artery occlusion. Stroke 2015;46:2322-4. (PMID:26111890).

21. Olson EA, Lentz K. Central retinal artery occlusion: a literature review and the rationale for hyperbaric oxygen therapy. Mo Med 2016;113:53-7. (PMID:27039492).

22. Olson EA, Lentz K. Central retinal artery occlusion: a literature review and the rationale for hyperbaric oxygen therapy. Mo Med 2016;113:53-7. (PMID:27039492).

23. Schrag M, Youn T, Schindler J, Kirshner H, Greer D. Intravenous fibrinolytic therapy in central retinal artery occlusion: a patient-level meta-analysis. JAMA Neurol 2015;72:1148-54. (PMID:26258861).

24. Shinoda K, Yamada K, Matsumoto CS, Kimoto K, Nakatsuka K. Changes in retinal thickness are correlated with alterations of electroretinogram in eyes with central retinal artery occlusion. Graefes Arch Clin Exp Ophthalmol 2008;246:949-54. (PMID:18425524).

25. Weiss JN. Hyperbaric oxygen treatment of nonacute central retinal artery occlusion. Undersea Hyperb Med 2009;36:401-5. (PMID:20112531). 